Egyptian Poultry Science Journal

http://www.epsaegypt.com

ISSN: 1110-5623 (Print) - 2090-0570 (On line)

\title{
EFFECT OF USING GERMINATED MORINGA OLEIFERA SEEDS ON JAPANESE QUAIL GROWTH PERFORMANCE
}

\author{
M.A.M ,Mousa, Riry, F.H. Shata, Kout Elkloub, M. EL. Moustafa, \\ Youssef, S.F and Hanan, A.H. Alghonimy
}

Anim. Prod. Res. Institute, Agric. Rs. Center. Ministry of Agric. Dokki, Giza

Corresponding author : Kout Elkloub, Moustafa; E-mail: dr.koutelkloub@yahoo.com

\begin{abstract}
Received:10/05/2016
Accepted: 25/05/2016

ABSTRACT: The aim of the study was to investigate the effect of feeding Japanese quail chicks on diets supplemented with different levels of germinated Moringa Oleifera seed (GMOS) on productive performance, carcass characteristics and blood constituents. A total number of 252 unsexed seven days-old Japanese quail chicks were randomly distributed to 4 equal groups each containing 63 chicks in 3 replicates with 21 chicks each. Four experimental diets supplemented with GMOS were formulated as follows: 0\% (control), $0.25 \%, 0.50 \%$ and $0.75 \%$ GMOS for $7-42$ days.

The results showed that, birds fed GMOS at levels $0.75 \%$ followed by $0.50 \%$ had significantly higher body weight and body weight gain than birds fed the control diet. The feed consumption showed no difference in all treatments. The best feed conversion ratio and European Production Efficiency Index (EPEI) obtained by using 0.75\% GMOS compared to control group. Abdominal fat significantly decreased by feeding levels 0.25 , 0.50 , and $0.75 \%$ GMOS respectively compared to the control group. Birds fed on GMOS significantly increased bursa percentages by using all levels of GMOS compared to control group. Plasma ALT decreased by using 0.75\% GMOS compared to control. However, AST decreased in all levels of GMOS with no difference compared to the control. Plasma cholesterol had lower level in all treatments compared to control group. In addition, HDL fraction was increased and LDL fraction was decreased in all treatments of GMOS. Total antioxidant capacity was significantly increased in group fed $0.50 \%$ GMOS compared to other treatments. It could by conclude that using GMOS $(0.25,0.50$ and $0.75 \%)$ improved performance, immune organs and blood constituents. The best level occurred by $0.75 \%$ GMOS in Japanese quails diets during the growing period (1-42 day).
\end{abstract}

Key words: Japanese Quail, Moringa Oleifera Seed, Performance. 


\section{INTRODUCTION}

Moringa oleifera is one of the plants that can be utilized in the preparation of poultry feeds. The plant apart from being a good source of vitamins and amino acids, it has medicinal uses (Makkar and Becker., 1999). Researchers have great interest in finding natural growth promoters to enhance poultry production and to reduce feed cost. Plant products have been used for centuries by humans as food and to treat ailments. Natural medicinal products originating from herbs and spices have also been used as feed additives for farm animals (Guo, 2003). Moringa oleifera is a plant posses multiple advantages. Different parts of the tree (leaves, fruits, immature pods and flowers) are edibles and entered in traditional diets in many tropics and subtropics countries (Siddhuraju and Becker, 2003 and Anhwange et al.,2004). The antioxidant compounds (phenols, Vitamin C, Vitamin E, $\beta$ carotene, zinc, selenium, flavonoids) in Moringa oleifera have been reported to improve shelf-life and the quality of meat products in the postslaughter stages (Valeria and Williams, 2011). Moringa is concentrated in nutrients and in the raw form seems to reduce the activity of pathogenic bacteria and moulds and improves the digestibility of other foods, thus helping chickens to express their natural genetic potential (Gaia, 2005). Eilert et al. (1981) reported that Moringa oleifera seeds have antimicrobial effects. Madsen et al. (1987) found that use of Moringa oleifera seeds reduced bacterial count of turbid Nile water in Sudan by 1-4 log units (90-99.9\%) within the first 1-2 hours of treatment. In addition, Walter et al. (2011) assured that Moringa oleifera and Moringa stenopetala methanol and n-hexane seed extracts produced inhibition effect on Salmonella typhii, Vibrio cholerae and Escherichia coli, which normally cause water borne diseases. Regarding chemical composition, Compaoré et al. (2011) reported that Moringa oleifera seeds are good source of fats, proteins and minerals. Kout Elkloub et al.( 2015) found that MOLM significantly decreased abdominal fat and plasma cholesterol especially LDL and improve performance, immune organs and blood constituents in Japanese quail.

The antioxidants activity of Moringa oleifera was higher than the conventional antioxidants such as ascorbic acid, which is also present in large amount in Moringa leaves (Siddhuraju and Becker, 2003). Atawodi (2010) found that Moringa oleifera contained polyphenols like ellagic acid, gallate, methylgallate, catechol, kaempferol quercetin. Also, Ogbe et al. (2013) found that Moringa oleifera seeds contained phytates $5.16 \%$, oxalates $1.45 \%$, saponins $2.94 \%$, tannins $3.30 \%$, trypsin inhibitors $1.42 \%$, hydrogen cyanide $0.05 \%$. Moringa oleifera is a highly valued food plant characterized by a multipurpose use (Anwar et al., 2007). Dietary supplementation of Moringa formulated diets for broilers was effective in enhancing the oxidative stability of chicken meat (Qwele et al., 2013).

Furthermore, Moringa oleifera seeds have been reported as good sources of the main feed ingredients including fats, proteins and minerals (Compaoré et al. 2011). Moringa oleifera can play an important role in the economy of poultry industry. Partial substitution of fish meal for Moringa oleifera leaf meal has been found to decrease the feed cost (Zanu et al. 2012).

The purpose of this study was to evaluate the effect of germinated Moringa oleifera seeds (GMOS) in the Japanese quail diet on their performance and carcass characteristics. 


\section{MATERIALS AND METHODS}

The experimental work was carried out at El - Fayoum Poultry Farm, Animal Production Research Institute, Agriculture Research Center, Ministry of Agriculture, Egypt.

Processing of Moringa oleifera seeds: Moringa oleifera seeds were collected sorted, cleaned were soaked in water for two days and then thoroughly washed with water and left cloth for 72 hours until germination and dried ground up to powder using grinding machine. These grounds up seeds powder were compounded into feed for the feeding.

Experimental Design and Management of birds: A total number of 252 unsexed birds of Japanese quail-7 days old were having nearly equaled live weights $(30 \mathrm{~g})$ were distributed randomly into four treatment groups. Sixty three birds were assigned to each treatment group, three replicates per each, each containing 21 birds. Birds were fed on $24 \%$ CP and 2900 Kcal. Table (1) shows composition and calculated analysis of diets. Dietary treatments were designed to contain 0.0 (control), $0.25,0.50$ and $0.75 \%$ germinated Moringa oleifera seed (GMOS) as growth promoters in Japanese quail diets. All birds received feed and water ad libitum. Body weight, feed consumption and mortality rate were recorded biweekly and average body weight gains, feed conversion ratio and European Production Efficiency Index (EPEI) was calculated guide (1999).

EPEI = BW $(\mathrm{kg}) \times \mathrm{LA} \times 100 / \mathrm{PP} \times \mathrm{FCR}$.

Where:

BW : Body weight $(\mathrm{kg})$.

LA : Livability (100-\% mortality)

PP :Production period (days)

FCR : Feed conversion ratio ( $\mathrm{kg}$ feed / kg gain).

At the end of the experiment (42 day), three birds from each treatment were slaughtered to obtain the carcass; giblets (gizzard, liver and heart) and the lymphoid organs were separately weighed. Blood samples were taken to determine serum content of total protein, glucose, albumin, globulin, cholesterol, calcium, phosphor and liver enzymatic activity (AST and ALT) using commercial kits.

Obtained data were statistically analyzed using linear models procedure described in SAS users guide (SAS, 1990). Differences among means were tested using Duncan's multiple range tests (Duncan's, 1955). One - way analysis model was applied for experiment:

$\mathrm{Y}_{\mathrm{ij}}=\mu+\mathrm{T}_{\mathrm{i}}+\mathrm{E}_{\mathrm{ij}}$

Where: $\mathrm{Y}_{\mathrm{ij}}=$ Observations

$$
\begin{aligned}
\mu & =\text { The overall mean } \\
\mathrm{Ti} & =\text { Effect of } \mathrm{i}^{\text {th }} \text { treatments } \\
\mathrm{E}_{\mathrm{ij}} & =\text { Experimental error }
\end{aligned}
$$

\section{RESULTS AND DISCUSSION}

Growth performance: Body weight (BW), body weight gain (BWG), feed consumption (FC), feed conversion ratio (FCR), mortality rate (MR) and European Production Efficiency Index (EPEI) are showed in Table 2. All levels of GMOS $(0.25, \quad 0.50$ and $0.75 \%)$ resulted in significant increased $\mathrm{BW}$ and $\mathrm{BWG}$ at all period of the experiment $(14,28$ and 42 day) compared to control group, except $0.25 \%$ at 28 and 42 day which recorded insignificant increase in BW and BWG. The level of $0.75 \%$ was achieved the best BW and BWG followed by $0.50 \%$ then $0.25 \%$.

The average feed consumption (FC) during 7-14d of age was significantly different among all treatments compared to the control which achieved increased in feed consumption, while, no differences were observed in periods of $15-28,29-42$ and 7-42 day in FC between all treatments. The feed conversion ratio (FCR) was significantly improved by using all levels of GMOS in all period of the experiment compared to control group. Generally, $0.75 \%$ followed by $0.50 \%$ GMOS achieved the best FCR in the overall period (7 - 42 day). This may be attributed to birds fed GMOS based diets adequately 
utilized the nutrients they consumed. This improvement in body weight gain and FCR may be attributed to rich content of nutrients in germinated Moringa oleifera seed (Toye et al., 2013) and antimicrobial properties of Moringa (Fahey et al.,2001). The improved weight gain of birds fed on GMOS compared to control group may be due to Moringa oleifera seeds good source of fat, protein, antioxidants and minerals (Compaoré et al., 2011). This effect of GMOS leads to higher daily weight gain and improve feed conversion ratio in Japanese quail. These results are in harmony with the finding of Abbas and Ahmed (2012) who used Moringa oleifera seed powder at levels $0.37,0.75,1.5 \%$ and observed level $0.37 \%$ increased live body weight compared to control. On the other hand, Olaniyan (2012) reported that feeding 10\% Moringa seed to broilers increased live body weight than the control diet. Also these results are in agreement with Ochi et al. (2015) who mentioned that the inclusion of Moringa oleifera seed powder (MOSP) at levels $0.5,1$ and $2 \%$ in the diet of the broilers significantly $(\mathrm{P} \leq 0.05)$ enhanced their body weight, weight gain and feed consumption. While, during starter period a reduction in body weight, weight gain and feed efficiency as a result of the addition of higher level of MOSP $(2.0 \%)$ to broilers diet. This may be due to the presence of phytates which is an anti-nutritional factor. Phytates was reported to reduce bioavailability of minerals in non- ruminant animals (Reddy et al. 1982) and decline digestibility of starch and protein (Thompson 1993). In present study, the positive results may be due to the treatment process, which the seeds soaked in water for two days and then thoroughly washed with water and left cloth for 72 hours until germination and ground up to powder which it may be due to led to get rid of the negative effects and the removal of toxic and cracking complex nutrients and make them into a simple image makes it easier for the bird to take advantage of them better soak.

Table 2 showed the effect of dietary treatments on mortality. The absence of death cases among the birds might be due to anti- microbial and availability of vitamins, proteins and minerals in Moringa plant which may increase the immunity, besides the good house management during the experiment (which may be increased livability of control group). This is in line with the findings of Abbas and Ahmed (2012) who revealed no case of death among the broilers fed germinated Moringa oleifera seed (GMOS) in the diet. These results agreed with those obtained by Ochi et al. (2015) who reported that non adverse effect on mortality rate of birds receiving dietary MOSP.

The technical evaluation expressed as European Production Efficiency Index (EPEI) in the present study (Table 2) cleared that feeding Japanese quail chicks on diets supplemented with $0.75 \%$ GMOS recorded significantly the highest EPEI value (20.72) than those fed other treatments and control group followed by $0.50 \%$. This result due to the increase in BWG and improve FCR in addition of livability.

Carcass characteristics: Statistical analyses of carcass yield in different groups are showed in Table 3. The dietary supplementations of GMOS did not affect relative weights of dressing, breast, liver, heart, giblets and total edible parts. On the other hand, abdominal fat was significantly decreased by decreasing levels of GMOS compared to control group. Also, Gizzard significantly decreased by using all levels of GMOS compared to control group. This result agree with Ochi et al. (2015) who used 0.5, 1 and 2\% Moringa oleifera seed powder (MOSP) in the broiler chicks' diet and observed that $0.5 \%$ MOSP resulted in significant $(\mathrm{P} \leq 0.05)$ lower weight of gizzard compared to control diet. Abdominal fat weight showed significant 
$(\mathrm{P} \leq 0.05)$ differences with all treatments of MOSP.

Results in Table 3, showed significantly increased of bursa relative weight by feeding all levels of GMOS compared to control group. Also, the level of $0.25 \%$ MOSP significantly improved the percentage of thymus compared to the control and other treatments. These results may be due to antioxidant activities of some components of Moringa oleifera like vitamins $\mathrm{C}$ and $\mathrm{E}$ (Rocha $\boldsymbol{e t}$ al.,2010) and phenols especially flavonoids (Diallo $\boldsymbol{e t}$ al., 2009) and to the capacity of plants polysaccharides to modulate the immune system (Dong et al ., 2007). Same results were obtained in broiler chicks fed different levels of MOLM; 0, 2 and 4\% (ELDeeb et al. , 2014) and in Japanese quail fed different levels of MOLM;0.2, 0.4 and $0.6 \%$ (Kout Elkloub et al. ,2015).

Blood constituents: The results of the estimated blood plasma parameters at 42 days old as affected by dietary germinated Moringa oleifera seed (GMOS) are presented in Table 4.

Plasma calcium significantly decreased when used GMOS compared to control group in spite of calcium levels are within normal physiological levels. While, phosphorus was not affected with all treatment. Plasma ALT significantly decreased with all levels of GMOS compared to control group and the lowest value occurred by using of $0.75 \%$ GMOS. On the other hand AST insignificantly decreased when used 0.50 and $0.75 \%$ GMOS compared to the control. Since liver is reported to contain enzymes like ALT and AST, it releases these enzymes to the blood when damaged (Kaplan et al., 2003). Hence, the absence of significant differences among treatment diets in plasma AST in the present study may reflect normal liver function of the birds fed diets containing MOSP. The decrease in ALT activity observed in birds on diet contained $0.75 \%$ and $0.5 \%$ MOSP could suggest that MOSP has properties that can enhance liver health.

Plasma cholesterol was reduced in all treatments compared to control (Table 4). The lowest cholesterol value occurred by $0.25 \%$ GMOS followed by 0.50 then $0.75 \%$ compared to control group. In addition, HDL fraction was increased and LDL fraction was significantly decreased in all treatments compared to control group. These results could be proved the effect of GMOS on plasma cholesterol reduction especially LDL. Similar results have been obtained by Durgesh et al. (2013) who found that significant $(\mathrm{P} \leq$ $0.01)$ reduction in total cholesterol and LDL-cholesterol and increase in HDLcholesterol in GMOS supplemented birds. The concentrations of total antioxidants capacity values was significantly increased by $0.50 \%$ GMOS compared to control (Table 4).

No significant effect of GMOS levels on plasma glucose except $0.50 \%$. Also, no significant differences were observed between all treatments in total protein, albumin and globulin, in spit of globulin had higher level in all treatments $(0.25$, 0.50 and $0.75 \%$ ) compared to control group.

In addition to, $A / G$ ratio in all dietary treatments appeared to be decreased this means that immunity of birds fed different GMOS additives was improved compared to the control group. This result supported by Olugbemi et al. (2010) and ELDeeb et al. (2014)who reported that Moringa oleifera leaves had a beneficial effect on the immune responses of broilers. Same result was obtained by Kout Elkloub et al. (2015) in Japanese quails.

\section{CONCLUSION}

It could be concluded that germinated Moringa oleifera seed (GMOS) improved performance, immune organs and blood constituents at levels $0.25,0.50$ and $0.75 \%$. The best level occurred by $0.75 \%$ in Japanese quail diets. 
Table (1): The composition and calculated analysis of diet.

\begin{tabular}{|l|c|}
\hline \multicolumn{1}{|c|}{ INGREDIENTS } & \% \\
\hline Yellow corn & 55.39 \\
Soybean meal 44\% & 34.35 \\
Corn gluten 62\% & 7.30 \\
Dicalcium phosphate & 0.80 \\
Limestone & 1.35 \\
Salt NaCl & 0.35 \\
Premix (V\&M.) * & 0.30 \\
DL.Methionine & 0.05 \\
L.Lysine & 0.11 \\
Total & 100 \\
Calculated values \% & 24 \\
CP\% & 2900 \\
ME.KCal/Kg & 0.81 \\
Ca \% & 0.30 \\
Avail. P\% & 0.50 \\
Meth. \% & 1.3 \\
Lysine\% & \\
& \\
\hline
\end{tabular}

*Each $3 \mathrm{~kg}$ contains: 15000.000 IU Vit. A, 4000.000 IU Vit. $\mathrm{D}_{3}, 50000 \mathrm{mg}$ Vit. E, $4000 \mathrm{mg}$ Vit. $\mathrm{K}_{3}$, 3000mg Vit. $\mathrm{B}_{1}$, 8000mg Vit. $\mathrm{B}_{2}$, 5000mg Vit. $\mathrm{B}_{6}, 16000 \mathrm{mg}$ pantothenic acid, 20mg Vit. B12,2000mgfolicacid,4500mgniacin,200mgbiotin,7500mgzinc,500000 mgcholine, $15000 \mathrm{mgcopper}, \quad 150 \mathrm{mg}$ cobalt,1000mg iodine, $150 \mathrm{mg}$ selenium, 100000mgmanganese, 30000mg iron, carrier caco3 add to 3 $\mathrm{kg}$ 
Table (2): Effect of dietary germinated Moringa oleifera seed (GMOS) on growth performance and EPEI of Japanese quails.

\begin{tabular}{|c|c|c|c|c|c|}
\hline Treatment parameter & $\begin{array}{c}\text { 0\% } \\
\text { GMOS }\end{array}$ & $\begin{array}{l}\text { 0.25\% } \\
\text { GMOS }\end{array}$ & $\begin{array}{l}\mathbf{0 . 5 0 \%} \\
\text { GMOS }\end{array}$ & $\begin{array}{l}0.75 \% \\
\text { GMOS }\end{array}$ & SEM \\
\hline $\begin{array}{l}\text { Body weight }(\mathrm{g} / \mathrm{wk}) \\
7 \text { day } \\
14 \text { day } \\
28 \text { day } \\
42 \text { day }\end{array}$ & $\begin{array}{c}31.00 \\
69.00^{\mathrm{d}} \\
161.00^{\mathrm{b}} \\
223.00^{\mathrm{b}}\end{array}$ & $\begin{array}{c}31.00 \\
72.00^{\mathrm{c}} \\
172.00^{\mathrm{b}} \\
235.00^{\mathrm{b}}\end{array}$ & $\begin{array}{c}31.00 \\
75.00^{\mathrm{b}} \\
192.00^{\mathrm{a}} \\
259.00^{\mathrm{a}}\end{array}$ & $\begin{array}{c}31.00 \\
79.00^{\mathrm{a}} \\
200.00^{\mathrm{a}} \\
272.00^{\mathrm{a}}\end{array}$ & $\begin{array}{l} \pm 0.045 \\
\pm 0.762 \\
\pm 5.513 \\
\pm 6.296\end{array}$ \\
\hline $\begin{array}{l}\text { Body weight gain }(\mathrm{g} / \mathrm{wk}) \\
7-14 \text { day } \\
15-28 \text { day } \\
29-42 \text { day } \\
7-42 \text { day }\end{array}$ & $\begin{array}{c}38.00^{\mathrm{d}} \\
92.00^{\mathrm{b}} \\
62.00^{\mathrm{b}} \\
192.00^{\mathrm{b}}\end{array}$ & $\begin{array}{c}41.00^{\mathrm{c}} \\
100.00^{\mathrm{b}} \\
63.00^{\mathrm{b}} \\
204.00^{\mathrm{b}}\end{array}$ & $\begin{array}{c}44.00^{\mathrm{b}} \\
117.00^{\mathrm{a}} \\
67.00^{\mathrm{b}} \\
228.00^{\mathrm{a}}\end{array}$ & $\begin{array}{c}48.00^{\mathrm{a}} \\
121.00^{\mathrm{a}} \\
72.00^{\mathrm{a}} \\
241.00^{\mathrm{a}}\end{array}$ & $\begin{array}{c} \pm 0.751 \\
\pm 5.071 \\
\pm 2.631 \\
\pm 6.33\end{array}$ \\
\hline $\begin{array}{l}\text { Feed consumption }(\mathrm{g} / \mathrm{wk}) \\
7-14 \text { day } \\
15-28 \text { day } \\
29-42 \text { day } \\
7-42 \text { day }\end{array}$ & $\begin{array}{l}98.00^{\mathrm{a}} \\
259.00 \\
332.00 \\
689.00\end{array}$ & $\begin{array}{l}92.00^{c} \\
269.00 \\
293.00 \\
654.00\end{array}$ & $\begin{array}{l}86.00^{\mathrm{d}} \\
296.00 \\
325.00 \\
706.00\end{array}$ & $\begin{array}{l}96.00^{\mathrm{b}} \\
300.00 \\
299.00 \\
694.00\end{array}$ & $\begin{array}{l} \pm 0.577 \\
\pm 13.25 \\
\pm 16.39 \\
\pm 22.95 \\
\end{array}$ \\
\hline $\begin{array}{l}\text { Feed conversion ratio } \\
7-14 \text { day } \\
15-28 \text { day } \\
29-42 \text { day } \\
7-42 \text { day }\end{array}$ & $\begin{array}{l}2.58^{\mathrm{a}} \\
2.82 \\
5.35^{\mathrm{a}} \\
3.59^{\mathrm{a}}\end{array}$ & $\begin{array}{c}2.24^{\mathrm{b}} \\
2.69 \\
4.65^{\mathrm{b}} \\
3.21^{\mathrm{ab}}\end{array}$ & $\begin{array}{l}1.95^{\mathrm{c}} \\
2.53 \\
4.85^{\mathrm{b}} \\
3.10^{\mathrm{b}}\end{array}$ & $\begin{array}{l}2.00^{\mathrm{c}} \\
2.48 \\
4.15^{\mathrm{c}} \\
2.88^{\mathrm{c}}\end{array}$ & $\begin{array}{l} \pm 0.116 \\
\pm 0.149 \\
\pm 0.146 \\
\pm 0.105\end{array}$ \\
\hline MR\%* & 0.00 & 0.00 & 0.00 & 0.00 & \\
\hline EPEI** & $14.58^{\mathrm{c}}$ & $15.78 b^{c}$ & $18.37^{\mathrm{ab}}$ & $20.72^{\mathrm{a}}$ & \pm 0.921 \\
\hline
\end{tabular}

$a, b, c$ means in the same row with different superscripts are significantly different $(p \leq 0.01)$. *MR: Mortality rate.

**EPEI: European Production Efficiency Index 
Table (3): Effect of dietary germinated Moringa oleifera seed (GMOS) on carcass characteristics and lymphoid organs of Japanese quail at 42 days old.

\begin{tabular}{|l|c|c|c|c|c|}
\hline \multicolumn{1}{|c|}{ Items } & $\begin{array}{c}\mathbf{0 \%} \\
\text { GMOS }\end{array}$ & $\begin{array}{c}\mathbf{0 . 2 5 \%} \\
\text { GMOS }\end{array}$ & $\begin{array}{c}\mathbf{0 . 5 0 \%} \\
\text { GMOS }\end{array}$ & $\begin{array}{c}\mathbf{0 . 7 5 \%} \\
\text { GMOS }\end{array}$ & SEM \\
\hline Live body weight (LBW) (g) & 217.67 & 244.83 & 230.00 & 233.67 & \pm 6.02 \\
Dressing\% & 72.71 & 73.03 & 74.61 & 74.40 & \pm 1.13 \\
Breast\% & 43.42 & 45.05 & 44.77 & 45.04 & \pm 0.99 \\
Thigh\% & $25.00^{\mathrm{ab}}$ & $23.89^{\mathrm{b}}$ & $26.01^{\mathrm{a}}$ & $25.14^{\mathrm{a}}$ & \pm 0.36 \\
Abdominal Fat\% & $0.43^{\mathrm{a}}$ & 0.00 & $0.22^{\mathrm{c}}$ & $0.29^{\mathrm{b}}$ & \pm 0.004 \\
Liver\% & 2.20 & 2.33 & 1.97 & 2.03 & \pm 0.24 \\
Gizzard\% & $2.01^{\mathrm{a}}$ & $1.79^{\mathrm{ab}}$ & $1.52^{\mathrm{b}}$ & $1.40^{\mathrm{b}}$ & \pm 0.14 \\
Heart\% & 0.89 & 0.92 & 0.94 & 0.81 & \pm 0.06 \\
Giblets\%* & 5.10 & 4.94 & 4.43 & 4.24 & \pm 0.25 \\
Total edible parts** & 77.82 & 78.07 & 79.04 & 78.64 & \pm 1.25 \\
\hline & \multicolumn{6}{|c|}{ Lymphoid organs } \\
Spleen\% & 0.06 & 0.09 & 0.06 & 0.07 & \pm 0.01 \\
Thymus\% & $0.23^{\mathrm{b}}$ & $0.37^{\mathrm{a}}$ & $0.22^{\mathrm{b}}$ & $0.23^{\mathrm{b}}$ & \pm 0.02 \\
Bursa\% & $0.09^{\mathrm{c}}$ & $0.17^{\mathrm{a}}$ & $0.16^{\mathrm{a}}$ & $0.12^{\mathrm{b}}$ & \pm 0.01 \\
\hline
\end{tabular}

$\mathrm{a}, \mathrm{b}, \mathrm{c}$ Means in the same row with different superscripts are Significantly different $(\mathrm{p} \leq$ $0.01)$.

$*$ Giblets $=$ Liver + Gizzard + Heart

** Total edible parts $=$ dressing + giblets

Table (4): Effect of dietary germinated Moringa oleifera seed (GMOS) on some blood constituents of Japanese quail at 42 days old.

\begin{tabular}{|l|c|c|c|c|c|}
\hline \multicolumn{1}{|c|}{ Items } & $\begin{array}{c}\mathbf{0 \%} \\
\text { MOSP }\end{array}$ & $\begin{array}{c}\mathbf{0 . 2 5 \%} \\
\text { MOSP }\end{array}$ & $\begin{array}{c}\mathbf{0 . 5 0 \%} \\
\text { MOSP }\end{array}$ & $\begin{array}{c}\mathbf{0 . 7 5 \%} \\
\text { MOSP }\end{array}$ & SE \\
\hline Calcium (mg/dl) & $10.43^{\mathrm{a}}$ & $10.28^{\mathrm{b}}$ & $10.18^{\mathrm{c}}$ & $10.18^{\mathrm{c}}$ & \pm 0.03 \\
Phosphorus (mg/dl) & 2.32 & 2.37 & 2.16 & 2.52 & \pm 0.13 \\
ALT (u/l) & $48.33^{\mathrm{a}}$ & $46.33^{\mathrm{ab}}$ & $41.00^{\mathrm{bc}}$ & $37.33^{\mathrm{c}}$ & \pm 1.96 \\
AST (u/l) & 12.00 & 14.80 & 10.73 & 11.50 & \pm 1.38 \\
Cholesterol (mg/dl) & $199.48^{\mathrm{a}}$ & $97.36^{\mathrm{c}}$ & $147.37^{\mathrm{b}}$ & $154.03^{\mathrm{b}}$ & \pm 7.42 \\
HDL (mg/dl) & 50.29 & 62.21 & 66.26 & 65.86 & \pm 5.88 \\
LDL (mg/dl) & $149.18^{\mathrm{a}}$ & $35.15^{\mathrm{c}}$ & $81.11^{\mathrm{b}}$ & $88.17^{\mathrm{b}}$ & \pm 11.61 \\
Total antioxidant capacity (mmole/l) & $0.53^{\mathrm{b}}$ & $0.54^{\mathrm{b}}$ & $0.58^{\mathrm{a}}$ & $0.55^{\mathrm{b}}$ & \pm 0.01 \\
T.Lipids (mg/dl) & $454.18^{\mathrm{b}}$ & $330.26^{\mathrm{c}}$ & $545.87^{\mathrm{a}}$ & $472.73^{\mathrm{b}}$ & \pm 10.53 \\
Glucose (mg/dl) & $154.29^{\mathrm{a}}$ & $156.39^{\mathrm{a}}$ & $134.78^{\mathrm{b}}$ & $155.47^{\mathrm{a}}$ & \pm 2.40 \\
T.Protein (g/dl) & 4.15 & 4.42 & 4.07 & 4.34 & \pm 0.17 \\
Albumin A (g/dl) & 1.78 & 1.69 & 1.43 & 1.40 & \pm 0.33 \\
Globulin G (g/dl) & 2.37 & 2.73 & 2.63 & 2.94 & \pm 0.38 \\
A/G ratio & 0.84 & 0.70 & 0.59 & 0.52 & \pm 0.24 \\
\hline
\end{tabular}

$\mathrm{a}, \mathrm{b}, \mathrm{c}$ Means in the same row with different superscripts are Significantly different $(\mathrm{p} \leq 0.01)$ 


\section{REFERENCES}

Abbas, T.E., and Ahmed, M.E. (2012). Use of Moringa oleifera seeds in broilers diet and its effects on the performance and carcass characteristics. International Journal of Applied Poultry Research,1, 1-4.

Anhwange, BA., Ajibola, VO and Oniye, SJ. (2004). Chemical studies of the seeds of Moringa oleifera (Lam.) and Detarium microcarpum (Guill and Sperr). J Biol Sci, 4: 711-715.

Anwar, F., Latif, S., Ashraf, M. and Gilani, A.H. (2007). "Moringa oleifera: a food plant with multiple medicinal uses", Phytotherapy Research , 21(1), 17-25.

Atawodi, SE. (2010). Nigerian foodstuffs with prostate cancer chemopreventive polyphenols. Infect Agent Cancer Sep23:6 Suppl. 2:S9.

Compaoré, W.R., Nikièma, P.A., Bassolé, H.I.N., Savadogo, A., Mouecoucou, J., Hounhouigan, D.J. and Traoré, S.A. (2011). "Chemical composition and antioxidative properties of seeds of Moringa oleifera and pulps of Parkia biglobosa and Adansonia digitata commonly used in food fortification in Burkina Faso", Current Research Journal of Biological Sciences, 3 (1): 64-72.

Diallo,A., Eklu-Gadegkeku, K., Mobio,T., Moukha, S., Agbonon,A. , Aklikokou,K., Creppy, E.E. and Gbeasso, M.(2009). Protective Effect of Moringa oleifera Lam. and Lannea kerstingii Extracts Against Cadmium and Ethanol-induced Lipid Peroxidation Journal of Pharmacology and Toxicology, 4. issue: 4 p: 160-166.

Dong, X.F., Gao, W.W., Tong, J.M., Jia, H.Q. Sa, R.N. and Zhang, Q.(2007). Effect of polysavone (alfalfa extract) on abdominal fat deposition and immunity in broiler chickens. Poult. Sci., 86: 1955-1959.

Duncan, D.B. (1955). Multiple range and multiple F tests. Biocmtrics, 11:1-42.

Durgesh, K.D., Jyotsun, D., Anil, K., and Retan, K.G. (2013). A Multipurpose tree Moringa oleifera. International Journal of pharmaceutical and chemical science. Vol. 2(1):165-171 .

Eilert, U., Wolters, B and Nahrstedt, A. (1981). The antibiotic principle of

Moringa oleifera and Moringa stenopetala. Planta Med, 42: 55-61.

ELDeeb, Mariam A; N. M. Essa; M. Younis and A.A.Saleh (2014). Utilization of Moringa ( Moringa oleifera) Leaves Meal As A NoneTraditional Feedstuff on Productive Performance of Broiler Chicks. $4^{\text {th }}$. Mediterranean Poultry Summit of the Mediterranean Poultry Network of the WPSA. September 2-5, 2014, Beirut, Lebanon. (Abs.)

Fahey, J.W., Zakmann, A.T. and Talalay, P. (2001). The chemical diversity and distribution of glucosinolates and isothiocyanaes among plants. Corrigendum Phytochemistry, 59: 200-237.

Gaia, S. (2005). Wonder tree 100 facts moringa fact 04 exceptional animal feed moringa as livestock feed \& pet food. Moringa Mission Trust. Available at: http://

gaiathelivingplanet.blogspot.com/2005/ 06/wondertree-100-facts-moringa-fact04. html (Accessed 31 October 2013).

Guo, FC. (2003). Mushroom and herb polysaccharides as alternative for antimicrobial growth promoters in poultry. Int. J App Poult Res, 1(1): 1-4.

Kaplan, L.A., Pesce, A. J. and Kazmierczak, S. C. (2003). Liver Function. In: Sherwin, J.E. (Ed.), Clinical Chemistry, fourth edition. Elsevier Science, St. Louis, Toronto. 
Kout Elkloub, M. EL. Moustafa., Riry, F.H. Shata., Mousa, M.A.M., Hanan, A.H.Alghonimy and Youssef, S.F. (2015). Effect of using moringa oleifera leaf meal on performance of Japanese quail. Egypt. Poult. Sci. Vol. (35): 10951108.

Makkar, H.P.S. and Becker, K. (1999). Plant toxins and detoxification methods to improve feed quality of tropical seeds reviewAsian-Australian Journal of Animal Science (3):467- 480

Madsen, M., Schlundt, J. and El-Omer, EF. (1987). Effect of water coagulated by seeds of Moringa oleifera on bacterial concentrations. J Trop Med Hygiene, 90:101-109.

Ochi, E. B., Elbushra, M.E., Fatur, M., Abubakr, O., and Ismail, H. A. (2015). Effect of Moringa (Moringa oleifera Lam) Seeds on The Performance and Carcass Characteristics of Broiler Chickens. Journal of natural sciences research. Vol.5 (8): 66-73.

Ogbe, AO., Ombugadu, S.B., DanAzumi, O.A. and Ayube, F. (2013). Oral administration of aqueous extract from Moringa oleifera seed, Gum Arabic and wild mushroom (Ganoderma sp): Effect on growth performance of broiler chickens in comparison with antibiotic, International Journal of medicinal plant and alternative medicine, Vol.1(2), 30-38.

Olaniyan, O.M. (2012). Nutrigenetic effects of Moringa oleifera Seed Meal on young broiler chickens B. Agric project, submitted to Department of Animal of Production University of Ilorin: 45-48.

Olugbemi, T.S., Mutayoba, S.K. and Lekule, F.P. (2010).Effect of Moringa (Moringaoleifera) inclusion in cassava based diets fed to broiler chickens. International Journal of Poultry Science 9: 363-367.
Qwele, K., Muchenje,V., Oyedemi, S.O. B., Moyo, .B. and Masika, P.J. (2013). Effect of dietary mixtures of moringa (Moringa oleifera) leaves, broiler finisher and crushed maize on anti-oxidative potential and physicochemical characteristics of breast meat from broilers African Journal of Biotechnology, 12(3): 290-298.

Reddy, N.R., Sathe, S.K, and Salunkhe, D.K. (1982)."Phytatesin legumes and cereals", Advance Food Research, 28,1-92.SAS Institute, 1990. SAS/STAT User's Guide: Statistics. Release 8.2 SAS Institute Inc., Cary, NC.

Rocha, J.S.R., Lara, L.J.C., Baiao, N.C., Vasconcelos, R.J.C., Barbosa, V.M., Pompeu, M.A. and Fernandes, M.N.S. (2010)._Antioxidant properties of vitamins in nutrition of broiler breeders and laying hens. World's Poult. Sci. J., 66: 261-270.

SAS Institute, (1990). SAS User, s Guide: Statistics. Version 5 Editin. SAS Institute Inc., Cary, NC, USA.

Siddhuraju, P. and Becker, K. (2003). Antioxidant properties of various solvent extracts of total phenolic constituents from three different agroclimatic origins of drumstick tree (Moringa oleifera Lam.) leaves. Journal of agricultural and food chemistry, 51:2144-2155.

Thompson, L.U. (1993).'Potential health benefits and problems associated with anti-nutrients with foods", Food Research International Journal, 26, 131-149.

Toye, A.A., Sola-Ojo, F.E., Olaniyan, O.M. and Ojo, V.(2013). Nutrigenetic effect of moringa oleifera seed meal on the biological growth programme of young broiler chickens. AGROSEARCH (Special Moringa (Edition) Vol. 3. (1): 149163.

Valeria, V. and Williams, P.(2011). Improving meat quality through natural 
antioxidants. Chilean J. Agric.Res., $71: 2$.

Walter, A., Samuel, W., Peter, A., and Joseph, O.( 2011). "Antibacterial activitywith foods", Food Research International Journal, 26, 131-149.
Zanu, H.K., Asiedu, P., Tampuori, M., Abada, M., and Asante, I. (2012). "Possibilities of using Moringa (Moringa oleifera) leaf meal as a partial substitute fish meal in broiler chickens", Journal of Animal Feed Research, 2, 7075.

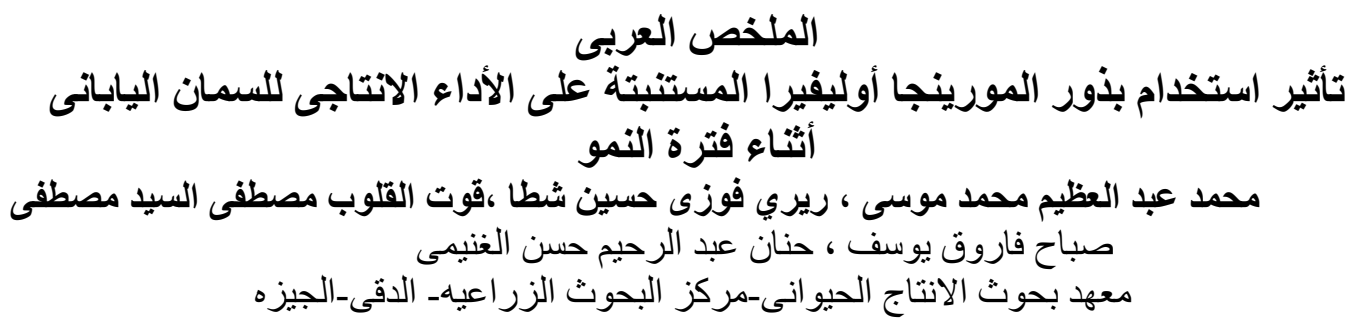

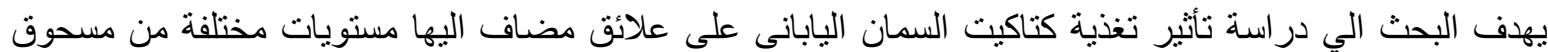

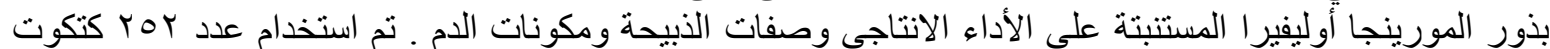

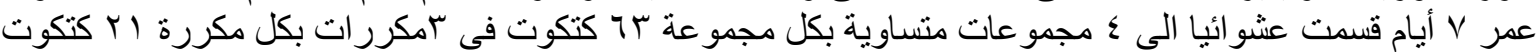

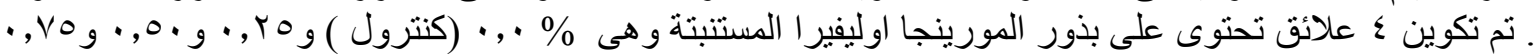

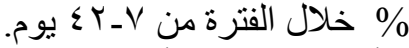

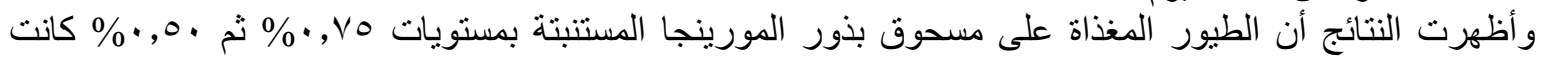

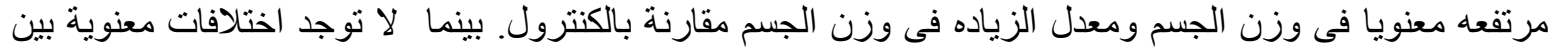

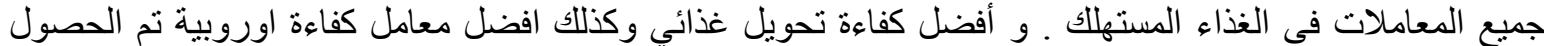

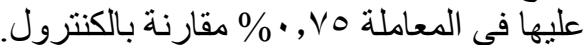

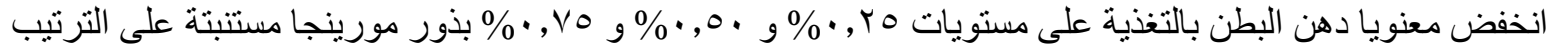

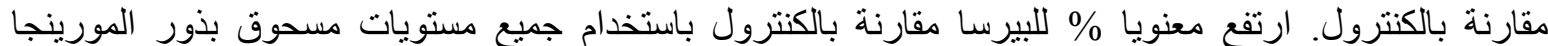
المستتبتة

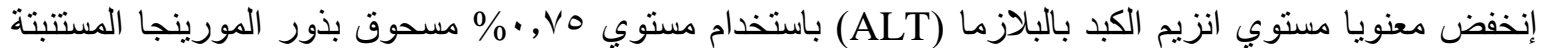

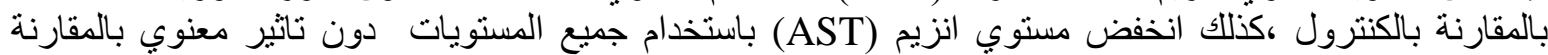

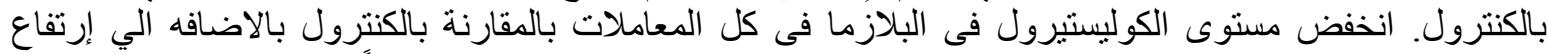

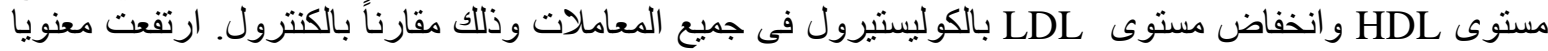

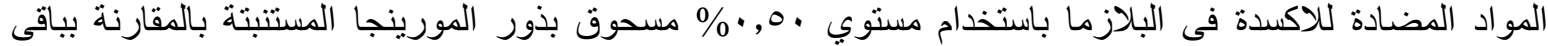

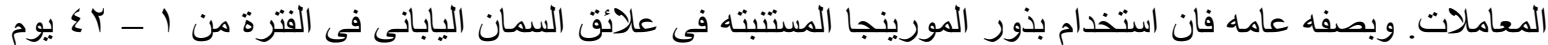

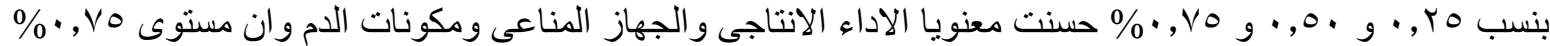
كان افضلها . 